\title{
The Intersection of U.S. Money Market Mutual Fund Reforms, Bank Liquidity Requirements, and the Federal Home Loan Bank System
}

\author{
Kenechukwu Anadu and Viktoria Baklanova
}

Risk and Policy Analysis (RPA) Working Papers present economic, financial and policy-related research conducted by staff in the Federal Reserve Bank of Boston's Risk and Policy Analysis Unit. RPA Working Papers can be downloaded without charge at: http://www.bostonfed.org/bankinfo/qau/wp/ 


\title{
The Intersection of U.S. Money Market Mutual Fund Reforms, Bank Liquidity Requirements, and the Federal Home Loan Bank System
}

\author{
Kenechukwu Anadu and Viktoria Baklanova ${ }^{1}$
}

October 31, 2017

\section{Executive Summary}

The most recent changes to money market fund regulations have had a strong impact on the money fund industry. In the months leading up to the compliance date of the core provisions of the amended regulations, assets in prime money market funds declined significantly, while those in government funds increased contemporaneously. This reallocation from prime to government funds has contributed to the latter's increased demand for debt issued by the U.S. government and government-sponsored enterprises. The Federal Home Loan Bank (FHLBank) System played a key role in meeting this heightened demand for U.S. government-related assets with increased issuance of shortterm debt. The FHLBank System uses the funding obtained from money market funds to provide general liquidity to its members, including the largest U.S. banks. Large U.S. banks' increased borrowings from the FHLBank System are motivated, in large part, by other post-crisis regulations, specifically the liquidity coverage ratio (LCR). The intersection of money market mutual fund reforms and the LCR have contributed to the FHLBanks' increased reliance on short-term funding to finance relatively longer-term assets, primarily collateralized loans to its largest members. This funding model could be vulnerable to "runs" and impact financial markets and financial institutions in ways that are difficult to predict. While a funding run seems unlikely, it is often the violation of commonly held conventions that tend to pose financial stability risks. Indeed, runs on leveraged financial intermediaries engaged in maturity transformation have produced systemic risks issues in the past and are worthy of investigation and continuous monitoring.

JEL classification: D47, E50, G23, G28

Keywords: Federal Home Loan Banks, liquidity coverage ratio, money market mutual funds, short-term funding markets, systemic risk

\footnotetext{
${ }^{1}$ Kenechukwu Anadu (ken.anadu@bos.frb.org) is a financial markets specialist at the Federal Reserve Bank of Boston. Viktoria Baklanova (Viktoria.Baklanova@ofr.treasury.gov) is a senior financial analyst at the Office of Financial Research (OFR). This paper presents preliminary observations and is intended to stimulate discussion and elicit comments from interested readers. We thank, without implicating, Steffanie Brady, Jill Cetina, Christine Docherty, Michelle Flaherty, Greg Feldberg, W. Scott Frame, Katherine Gleason, Dasol Kim, John Levin, Borghan Narajabad, Joe Peek, Sharon Pichler, Stacey Schreft, Lane Teller, and Andrei Zlate for their helpful input. We are also grateful to Sean Baker and Daniel Stemp for their excellent research assistance. The views expressed in this paper are ours and do not necessarily reflect those of the Federal Reserve Bank of Boston, the Federal Reserve System, the OFR, or the U.S. Department of the Treasury. All errors and omissions are ours.
} 


\section{Introduction and Background}

The run on prime money market funds contributed to strains in the U.S. dollar short-term funding markets during the most recent financial crisis. ${ }^{2}$ In mid-September 2008, the Reserve Primary Fund, a large prime fund, announced that it could no longer maintain a stable \$1.00 transaction price (an event known colloquially as "breaking-the-buck") due to its exposure to Lehman debt. ${ }^{3}$ Following this announcement, investors redeemed hundreds of billions of dollars from prime funds, which were invested substantially in short-term corporate debt (e.g., commercial paper (CP) and certificates of deposit (CDs). Simultaneously, investments in government funds increased in a broad-based flight-to-quality. ${ }^{4}$ While the Reserve Primary Fund was the only money market fund to "break-the-buck" and, thus, pass through principal losses to its shareholders in 2008, other prime funds were just as vulnerable and could have met a similar fate absent support actions by their sponsors. ${ }^{5}$

Unprecedented official sector action stemmed the run from prime money market funds and, in effect, stabilized the short-term funding markets. These emergency actions included the Treasury Department's share price guarantee program for eligible money market funds and the Federal Reserve's liquidity facility for asset-backed commercial paper held by money market funds. ${ }^{6}$

\footnotetext{
${ }^{2}$ The President's Working Group on Financial Markets (PWG) noted the run on prime funds "contributed to severe dislocations in short-term credit markets and strains on the businesses and institutions that obtain funding in those markets." See PWG, "Money Market Fund Reform Options," October 2010, https://www.treasury.gov/press-center/pressreleases/Documents/10.21\%20PWG\%20Report\%20Final.pdf. See also, Baba et al, "US dollar money market funds and non-US banks," 2009, http://www.bis.org/publ/qtrpdf/r qt0903g.pdf

${ }^{3}$ The Reserve Primary Fund's $\$ 785$ million in Lehman debt was marked to $\$ 0$ after Lehman's failure. As a result, the net asset value of the Reserve Primary Fund dropped from $\$ 1.00$ to $\$ 0.97$. See http://www.primary-yieldplusinliquidation.com/pdf/PressRelease2008 0916.pdf.

${ }^{4}$ Assets in prime funds declined by about $\$ 450$ billion or 21 percent in the four weeks beginning Sept. 10, 2008. During this period, government funds attracted significant inflows. See McCabe, Patrick, "Cross section of money market fund risks and financial crises," 2010, https://www.federalreserve.gov/pubs/feds/2010/201051/201051pap.pdf

${ }^{5}$ At least 21 prime funds could have "broken-the-buck" absent a single identified instance of support (including cash infusions) from their sponsors. See Brady et al, "The Stability of Prime Money Market Mutual Funds: Sponsor Support from 2007 to 2011," 2012, https://www.bostonfed.org/publications/risk-and-policy-analysis/2012/the-stability-of-prime-money-marketmutual-funds-sponsor-support-from-2007-to-2011.aspx

${ }^{6}$ See https://www.treasury.gov/press-center/press-releases/Pages/hp1161.aspx. For additional information on emergency lending facilities established by the Federal Reserve, see

https://www.federalreserve.gov/monetarypolicy/bst lendingother.htm. See also Duygan-Bump et al, "How Effective Were the Federal Reserve Emergency Liquidity Facilities? Evidence from the Asset-Backed Commercial Paper Money Market Mutual Fund Liquidity Facility," 2010, https://www.bostonfed.org/publications/risk-and-policy-analysis/2010/how-effective-were-thefederal-reserve-emergency-liquidity-facilities-evidence-from-the-asset-backed-commercial-paper-money-market-mutual-fundliquidity-facility.aspx
} 
Since the Reserve Primary Fund's failure, the Securities and Exchange Commission (SEC) has adopted two rounds of reforms, one in 2010 and the other in 2014. ${ }^{7}$ The reforms were intended to strengthen liquidity and credit risk management practices, enhance reporting requirements, and address run risk in money market funds, among other things. The two main components of the 2014 amendments were: (1) a requirement that institutional prime and taxexempt funds transact at a floating net asset value (NAV), from the then-stable NAV structure, and (2) granting the board of a non-government fund the ability to impose liquidity fees and redemption gates if it breaches certain liquidity thresholds; government funds may opt-in if previously disclosed. In its 2014 adopting release, the SEC noted, among other things, that the floating NAV requirement is intended to reduce the first mover advantage inherent in a stable transaction price, and fees and gates are intended to directly address runs on funds.

In the months leading to the October 14, 2016 compliance deadline for the floating NAV and fees and gates requirements, significant assets migrated from prime and tax-exempt money market funds, which are statutorily subject to those provisions, into government funds, which are not. One key factor to facilitating this shift is the FHLBank System, which met government funds' increased demand for eligible securities with increased issuance of short-term debt.

Available data shows that the largest U.S. banks are the largest borrowers from the FHLBanks. Some of this increase in large U.S. banks' borrowing from the FHLBank System is attributable to the liquidity coverage ratio (LCR) requirement. The LCR, for regulatory purposes, treats short-term funding obtained from FHLBanks more favorably than funding obtained from the private markets (e.g., commercial paper). ${ }^{8}$ The LCR is a driver for banks to increase their holdings in HQLA, which are potentially purchased through advances from the FHLBanks. This increased demand for funding from the largest U.S. banks has, in turn, provided an incentive for the FHLBank System to increase its issuance of short-term debt; while money fund reforms have, in turn, increased the demand for FHLBank debt from government money funds. The

\footnotetext{
${ }^{7}$ See SEC, "SEC Approves Money Market Fund Reforms to Better Protect Investors," 2010, https://www.sec.gov/news/press/2010/2010-14.htm, and SEC, "SEC Adopts Money Market Fund Reform," 2014, https://www.sec.gov/news/press-release/2014-143.

${ }_{8}$ In a 2014 report, "Recent Trends in Federal Home Loan Bank Advances to JPMorgan Chase and Other Large Banks," the Office of the Inspector General of the Federal Housing Finance Agency noted, “...the surge in advances to the four largest member [banks of the FHLBank System] is attributable, in large part, to bank liquidity standards established by the international Basel Committee on Bank Supervision." The report states that from March 31, 2012, to Dec. 31, 2013, advances to these four system members surged by 158 percent to $\$ 135$ billion. See, https://fhfaoig.gov/Content/Files/EVL-2014-006 1.pdf
} 
result is the FHLBank System is increasingly using its balance sheet to intermediate the supply of cash from government money market funds and demand for funding from large U.S. banks.

The rest of this paper is structured as follows. We discuss the impact of the SEC's 2014 reforms on the money market industry and the broader money markets in Section 2. Section 3 provides background information on the FHLBanks and examines the money fund industry's increased holdings of their debt. The potential implications of money market funds' increased exposure to FHLBanks are outlined in the penultimate section. Finally, we offer some concluding remarks.

This paper is not intended to assess the efficacy of the SEC's amendments to money market fund rules or federal banking regulators' liquidity requirements for large banks and bank holding companies.

\section{Impact of 2014 Reforms on Industry Assets and Broader Money Markets}

Reforms have had a profound impact on the composition of money market funds, but only a transitory, thus far, effect on the broader money markets. In the nine months leading to October $14,2016,{ }^{9}$ assets in prime funds declined by over $\$ 1$ trillion (or 64 percent) to $\$ 562$ billion, while those in government funds increased by a similar magnitude. ${ }^{10}$ This shift was driven primarily by money fund investors' preference for stable NAV funds that are not subject to liquidity fees and redemption gates. ${ }^{11}$ This asset migration continued right up to the midOctober 2016 compliance deadline, but has since stabilized. Prime money fund assets are in excess of $\$ 642$ billion as of month-end August 2017 (see Figure 1).

\footnotetext{
${ }^{9}$ The compliance date for the floating NAV and liquidity fees and redemption gates provisions.

${ }^{10}$ Measurement period is January 2016 through October 2016. Source: SEC Form N-MFP.

${ }^{11}$ We note that many fund complexes converted prime funds into government funds. As such, this sentence encompasses prime-into-government shifts by money fund investors and those that emanated from conversions of prime funds into government funds by money fund sponsors, which were likely driven by money fund investors' preferences.
} 
Figure 1: Net assets in money funds by fund type. Assets in prime funds declined significantly, with an almost offsetting increase in government funds.

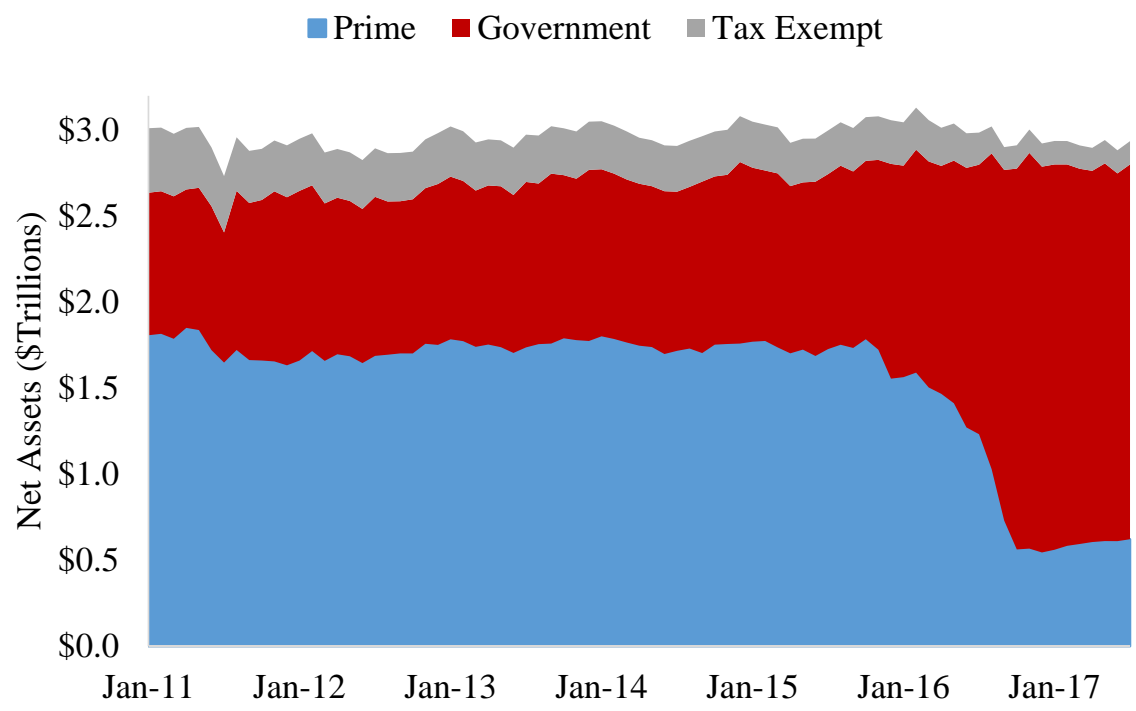

Source: SEC Form N-MFP. Data are monthly and through August 2017.

With regard to effects on the broader short-term funding markets, all else equal, a decline in prime fund assets is expected to reduce the supply of funding available to issuers of private unsecured short-term debt. Indeed, money funds' holdings of CP, CDs and other short-term securities issued by U.S. financial firms dropped by \$146 billion (66 percent) from January 2015 to August 2017, with most of the decline occurring in 2016 (see Figure 2). 
Figure 2: Prime money market funds' holdings of assets issued by U.S. financial firms declined sharply.

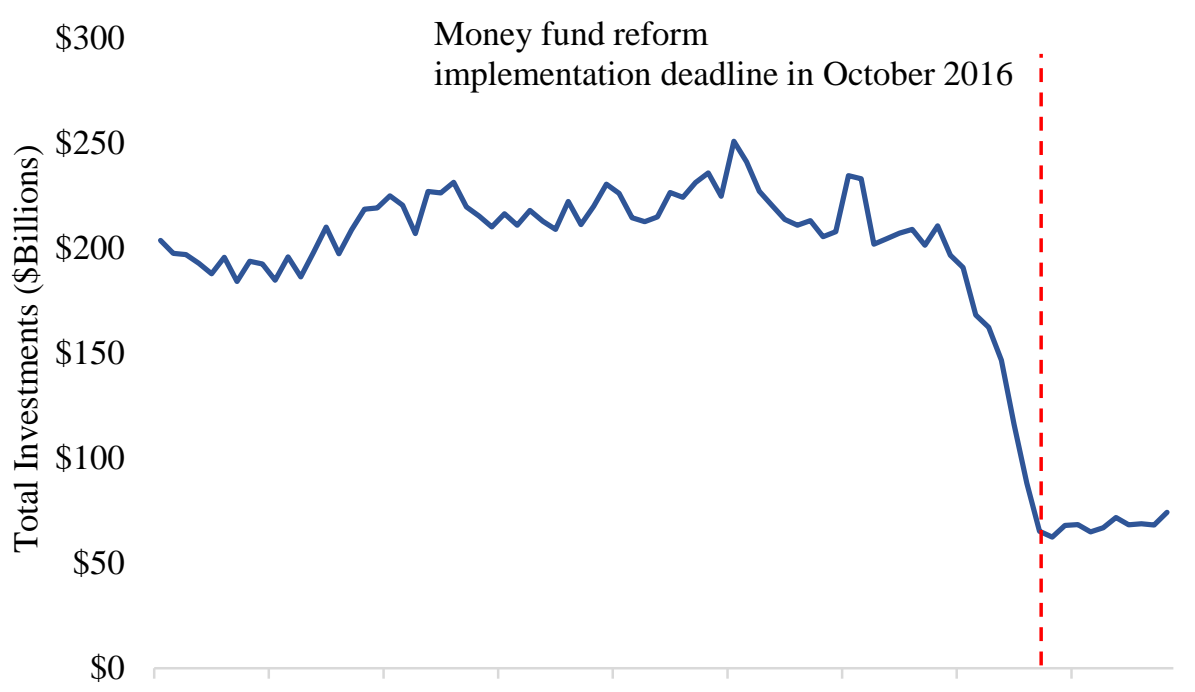

Jan-11 Oct-11 Jul-12 Apr-13 Jan-14 Oct-14 Jul-15 Apr-16 Jan-17

Source: SEC Form N-MFP. Data are monthly and through August 2017.

This reduced demand for unsecured short-term debt from money market funds likely contributed to increased volatility in certain indicators of U.S. dollar funding pressure. For example, the difference between the three-month London Interbank Offered Rate and the Overnight Indexed Swap rate (LIBOR-OIS spread), a measure of interbank funding costs, increased in the months leading to the reform's compliance date (mid-October), but has since reverted back to levels observed before that period (see Figure 3). 
Figure 3: Three-month LIBOR-OIS spread. Spreads widened in the months leading up to midOctober, but have since tightened.

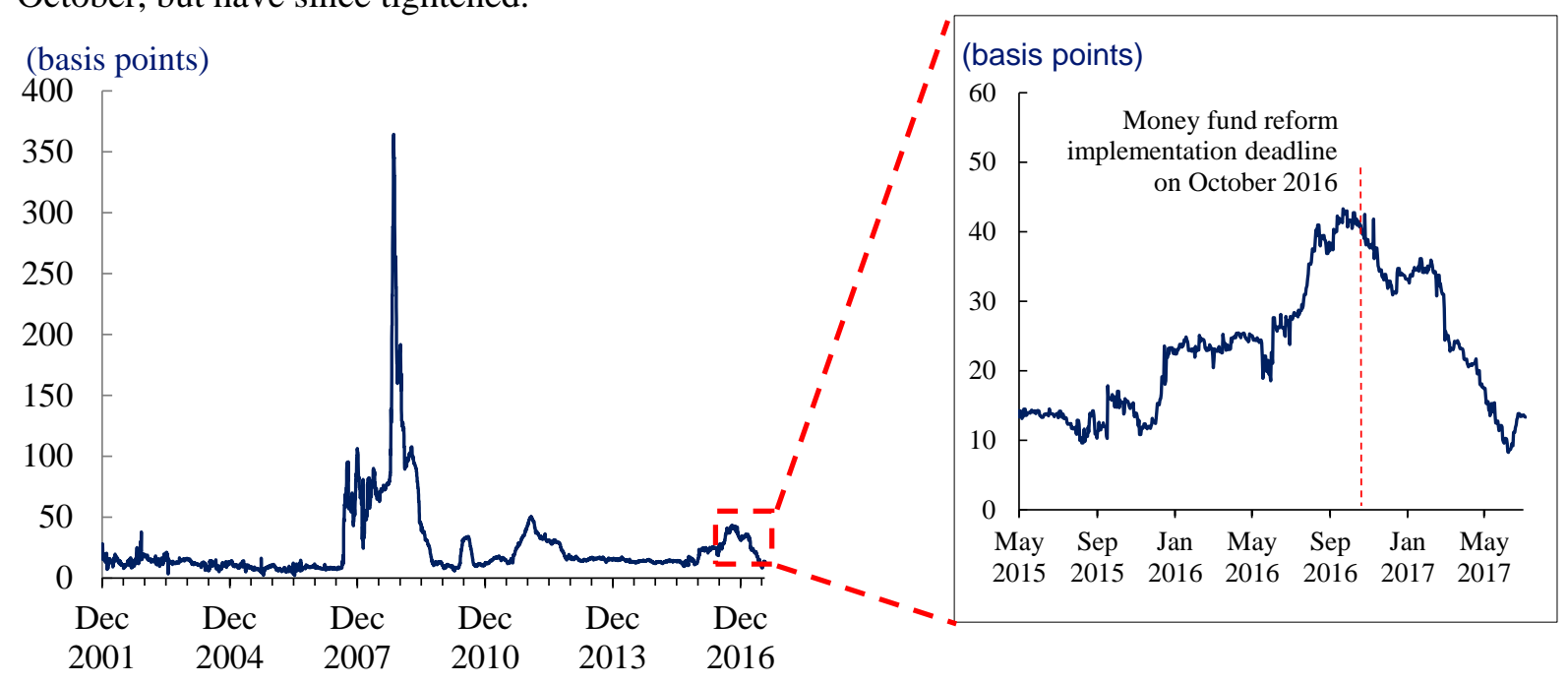

Source: Bloomberg Finance L.P. Data are daily.

LIBOR-OIS spreads tend to widen during periods of market stress. The increase in the second half of 2016 is quite modest compared to levels during the global financial crisis, although similar to levels during the European sovereign debt crisis. The relatively rapid reversal after the reform compliance deadline suggests the "spikes" were due to temporary supply and demand dynamics and not necessarily an indicator of emerging strains in the interbank funding markets. Banks and other borrowers adjusted to the reduced demand for unsecured private debt. U.S. banks, in particular, have turned to borrowing from government money funds indirectly through the FHLBanks, among other channels. This adjustment likely contributed to the narrowing of the LIBOR-OIS spread, since the falling supply of unsecured funding was met by a decline in demand as banks shifted to secured and other sources of funding. ${ }^{12}$

\section{Post-crisis Regulations and the FHLBank System}

As previously noted, $\$ 1$ trillion in assets have shifted from prime money market funds into government funds. As a result of the significant inflows, government funds have increased

\footnotetext{
${ }^{12}$ Similarly, cross-currency basis swap spreads (specifically EUR/USD and JPY/USD pairs) widened, as demand for U.S. dollar funding from non-U.S. borrowers increased, some of which would have otherwise been met by prime money market funds. To be sure, there are other factors that may be contributing to increased volatility in the foreign exchange swap markets, including certain post-crisis regulations and monetary policy differences. For a discussion, see, Borio et al, "Covered interest parity lost: understanding the cross-currency basis," 2016, http://www.bis.org/publ/qtrpdf/r qt1609e.htm. See also, Brauning et al, "Uncovering Covered Interest Parity: The Role of Bank Regulation and Monetary Policy," June 2017, https://www.bostonfed.org/publications/current-policy-perspectives/2017/uncovering-covered-interest-parity-the-role-ofbank-regulation-and-monetary-policy.aspx
} 
their investments in U.S. government and GSE debt. One development of particular interest is the FHLBanks' increased reliance on short-term funding from government money market mutual funds. Our examination of money funds' holdings and the FHLBank System's consolidated financial statements suggests that money market reforms are a significant driver of the FHLBanks' increased funding from government money market funds.

In addition to money fund reforms, we also point to the role that other post-crisis bank regulations may have played in money funds' increased holdings of debt issued by the FHLBank System. Specifically, the LCR, adopted in 2014, requires covered banking organizations to hold High Quality Liquid Assets (HQLA), including government debt, in an amount that is greater than or equal to the banks' projected net cash outflows during a 30-day stress period. For regulatory purposes, the LCR treats bank borrowings from FHLBanks more favorably than those from private markets. Thus, the rule incents covered banks to "transform" less liquid assets into HQLA, by, for example, pledging such assets (e.g., mortgage loans) as collateral when borrowing from the FHLBanks, and, in turn, investing the proceeds from the borrowings into HQLA. ${ }^{13}$

Next, we discuss the structure of the FHLBank System, its balance sheet activities, and the potential implications of the aforementioned development to the broader financial system.

\subsection{The FHLBank System}

The FHLBank System (a GSE) was established in 1932 to support mortgage lending by providing funding to its members, including commercial banks and credit unions. The system is comprised of 11 regional FHLBanks and has over 7,000 members. ${ }^{14}$ Each FHLBank is a separately-chartered entity with its own individual management and board of directors. There is no centralized board of director oversight across the 11 FHLBanks. The FHLBanks are subject to

\footnotetext{
${ }^{13}$ LCR is computed as: (LCR $\left.=\frac{\text { HQLA }}{30 \text {-day net stressed cash out flow }}>100 \%\right)$. "Transforming" illiquid assets into HQLA increases the numerator of the LCR, while having no (if the advances are greater than 30-days) or little (if advances mature within 30 days) impact on the denominator of the LCR. This is because the LCR assigns a maximum outflow rate of 25 percent to FHLBank advances that mature within 30 days, depending on the underlying collateral. This compares to 100 percent for general unsecured wholesale funding that is not fully insured (e.g., commercial paper). For more information on the LCR, see https://www.federalreserve.gov/newsevents/pressreleases/bcreg20140903a.htm.

${ }^{14}$ As of June 2017, the FHLBank System had 7,027 members. Commercial banks accounted for 63 percent of the total; credit unions, 20 percent; savings institutions, 11 percent. Insurance and community development financial institutions accounted for 6 percent and 1 percent, respectively. For more information on the system, see https://www.fhfa.gov/SupervisionRegulation/FederalHomeLoanBanks/Pages/About-FHL-Banks.aspx
} 
oversight by the Federal Housing Finance Agency (FHFA), which is charged with ensuring that GSEs, including the FHLBanks, "...operate in a safe and sound manner so that they serve as a reliable source of liquidity and funding for housing finance and community investment."15

The FHLBanks provide funding by making collateralized (primarily by mortgages) loans to its members known as "advances." Advances are a flexible source of funding that are available in various maturities. Advances may carry fixed or variable interest rates, and may contain call or put options. Member financial institutions generally use these advances to meet short-term liquidity needs, fund mortgages, or for general asset-liability purposes, among other things. ${ }^{16}$

Advances and other assets are primarily funded by discount notes and bonds issued by the FHLBank System. As GSEs, market participants generally view the system's consolidated debt obligations as implicitly guaranteed by the U.S. government, although the FHLBank System's public disclosures note that "...consolidated obligations are not obligations of the United States and are not guaranteed by either the United States or any government agency."17 This perception allows the FHLBanks to borrow at advantageous interest rates, presumably to the benefit of their members in the form of reduced interest rates on advances. ${ }^{18}$

In addition to providing collateralized loans to its members, the FHLBank System plays an important role in the money markets as a major lender in the federal funds market. ${ }^{19}$ The FHLBank System provides liquidity in certain mortgage markets by purchasing eligible loans from members. However, the System's role providing targeted support to the housing system has declined over the years. ${ }^{20}$

\footnotetext{
${ }^{15}$ See https://www.fhfa.gov/AboutUs

${ }^{16}$ Fixed rate advances generally mature within one to 30 years, while those that are variable have maturities that range from 30 days to 20 years, see http://www.fhlb-of.com/ofweb userWeb/resources/lendingqanda.pdf

${ }^{17}$ See for example, FHLBanks' March 2017 combined financial report, http://www.fhlbof.com/ofweb_userWeb/resources/2017Q1CFR.pdf

${ }_{18}$ See Frame, W. Scott, "The Federal Home Loan Bank System and U.S. Housing Finance," 2016, https://www.frbatlanta.org/research/publications/wp/2016/02.

${ }^{19}$ See Afonso et al, "Who's Lending in the Fed Funds Market?" 2003, http://libertystreeteconomics.newyorkfed.org/2013/12/whos-lending-in-the-fed-funds-market.html.

${ }^{20}$ W. Scott Frame (2016).
} 


\subsection{Trends in the consolidated assets and liabilities of the FHLBank System ${ }^{21}$}

During the most recent financial crisis, total FHLBank System assets peaked at about $\$ 1.4$ trillion, a period in which the FHLBanks acted as lender of next to the last resort to its members. ${ }^{22}$ Total assets then declined steadily until the first quarter of 2012 . Since then, the FHLBanks' consolidated balance sheet has resumed its growth and increased to over \$1 trillion.

Advances to member institutions are the System's largest asset category. Advances totaled $\$ 706$ billion or 65 percent of FHLBanks' consolidated assets, at the end of June 2017 (see Figure 4). About 49 percent of advances mature after one year of initial extension, when measured by contractual maturity. This ratio of longer-term advances to total advances outstanding has held relatively stable over the years, as discussed in Section 3.4 below. $^{23}$

Across the 11 FHLBanks, the size of advances relative to total assets ranged from 53 percent at FHLBank Indianapolis (tenth largest by assets) to 74 percent at FHLBank Pittsburgh (sixth largest by assets). Advances and other credit products are over-collateralized. The system had a combined loan-to-collateral ratio of 36 percent as of December 2016, although there is some hetegogentity in the effective lending values assigned to different collateral types across each FHLBank. ${ }^{24}$

\footnotetext{
${ }^{21}$ Although we do not discuss equity separately, we note that each FHLBank is subject to three regulatory capital requirements: (1) a risk-based capital, which requires each FHLBank to hold permanent stock and retained earnings in an amount equal to the sum of its credit, market, and operational risk capital requirements; (2) total regulatory capital, which mandates a minimum capital-to-assets ratio of four percent; and (3) leverage capital, which mandates a minimum leverage capital-to-assets ratio of five percent, with leverage capital defined: [(1.5* permanent capital) + (Other capital)]. As of month-end June, the average capital-to-asset ratio across all FHLBanks was 5.2 percent, with minimum and maximum ratios of 4.5 percent (FHLBank Topeka) and 6.2 percent (FHLBank San Francisco), respectively.

${ }^{22}$ W. Scott Frame (2016).

${ }^{23}$ When measured by contractual maturity or next call date, 34 percent of advances mature after one year. The analogous ratio for advances by contractual maturity or next put date is 48 percent. See page F-19 of http://www.fhlbof.com/ofweb userWeb/resources/2017Q2CFR.pdf

${ }^{24}$ For example, the effective lending value (100 percent minus the collateral haircut) applied to single-family mortgage loans (blanket liens) ranges from 21 percent to 96 percent, with an average effective lending value of 80 percent. See page 82 of http://www.fhlb-of.com/ofweb userWeb/resources/2016Q4CFR.pdf
} 
Figure 4: Composition of the FHLBank System's assets.
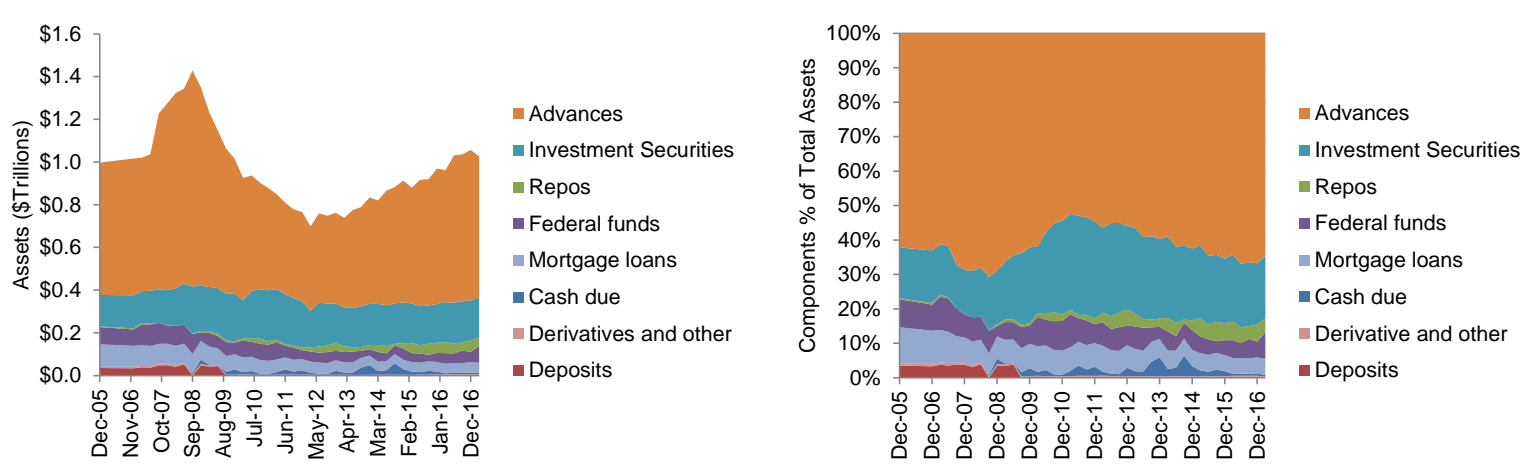

Source: FHLBanks' public SEC filings. Data are quarterly and through June 2017.

On the liability side, consolidated debt obligations are about $\$ 1$ trillion or 98 percent of FHLBanks’ total consolidated liabilities, as of month-end June 2017 (see Figure 5).

Consolidated debt obligations are comprised of discount notes ( $\$ 429$ billion or 42 percent of total debt obligations), which typically mature within 90 days, ${ }^{25}$ and bonds ( $\$ 582$ billion or 58

percent). It is notable that the FHLBanks have also increased their issuance of floating-rate notes over the past year. Over 62 percent of floaters issued by the FHLBank System in August mature within 12 months. In aggregate, about 79 percent of FHLBanks' consolidated obligations mature within one year and this ratio has trended upwards over the years, more so for discount notes (see Figure 5).

Consolidated obligations are joint and several liabilities of all 11 FHLBanks, even though each is a distinct entity with its own board and management. This means that each FHLBank is responsible for the timely repayment of consolidated debt issued by the FHLBank System. ${ }^{26}$

\footnotetext{
${ }^{25}$ The weighted average maturity of the FHLBanks' discount notes was 48 days, as of July 2017.

${ }^{26}$ We note that this structure, coupled with competition to increase lending, could result in underpricing of risk within the FHLBank System, as one bank's inability to repay its obligations is borne by the other ten. However, a discussion on this is outside the scope of this paper.
} 
Figure 5: Composition of the FHLBank System's liabilities.
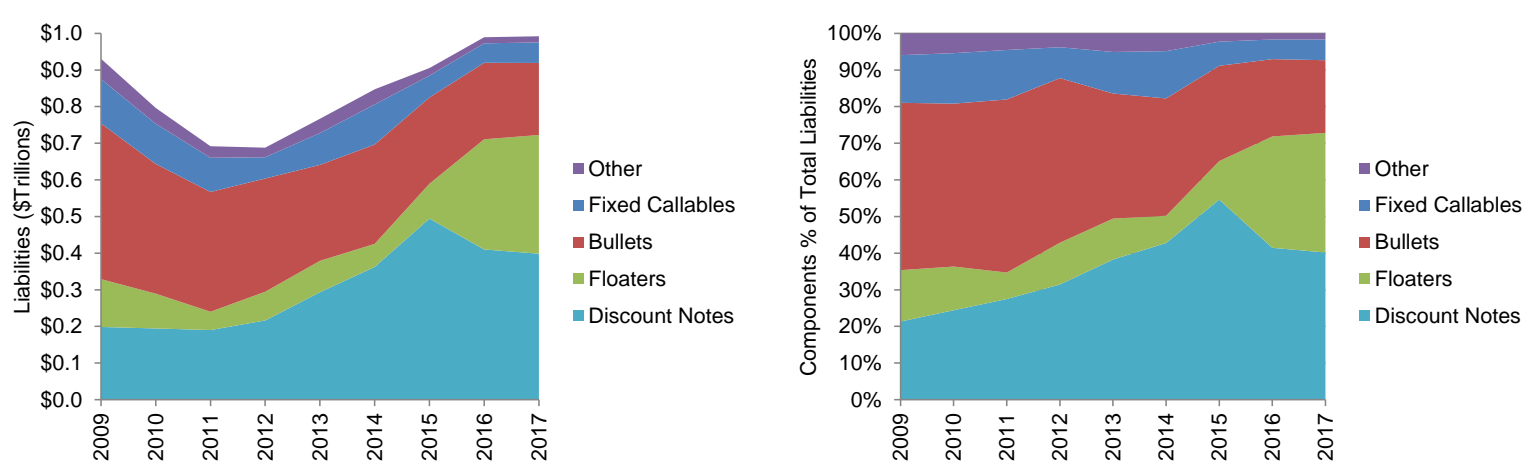

Source: FHLBanks' public SEC filings. Data are annual (last observation as of August 2017).

Figure 6: Maturity structure of the FHLBank System's debt obligations (components as a fraction of total FHLBank debt outstanding).

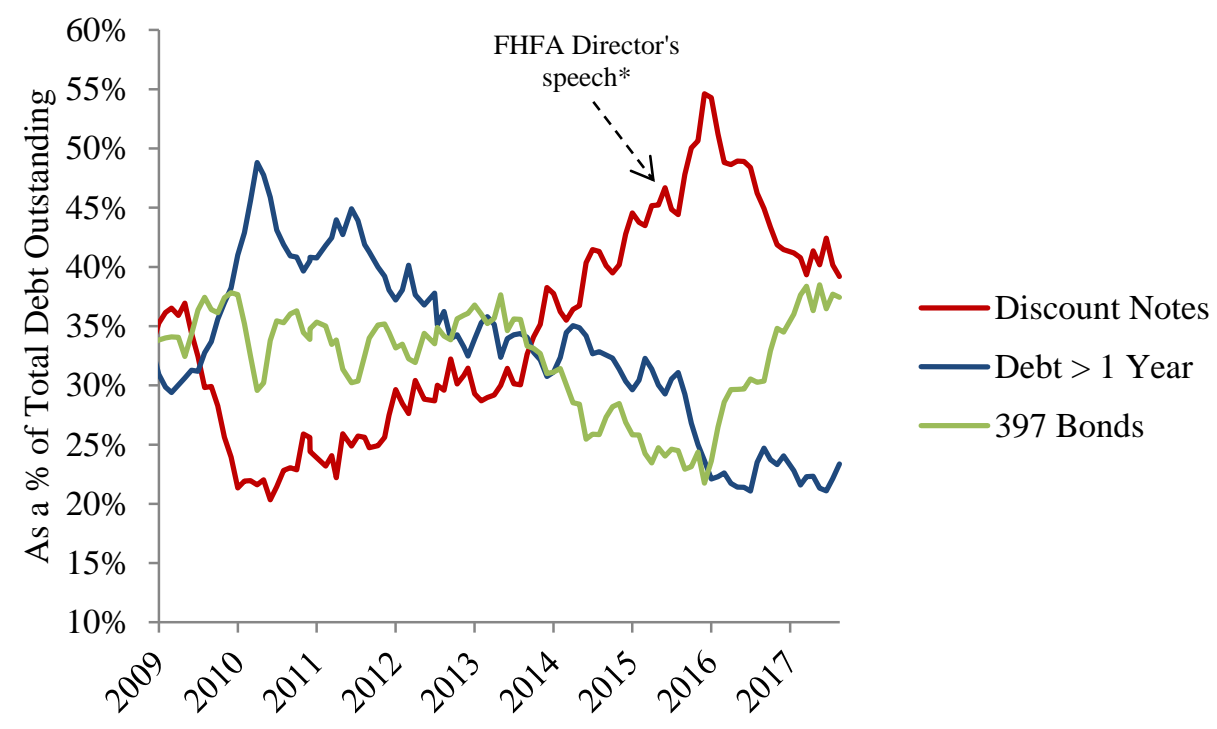

Sources: FHLBanks' public SEC filings, authors' calculations. Data are monthly through August 2017. Note: "397 bonds" mature within 397 days of issuance and are eligible for investments by money market funds. ${ }^{27}$ *The FHFA director first publicly expressed concerns with the FHLBank System's use of short-term funding.

We provide these data to illustrate how the FHLBank System's consolidated balance sheet has evolved before and after the most recent financial crisis. Next we describe borrower concentrations across the FHLBank system.

${ }^{27}$ See Rule 2a-7(a)(12)(i). 


\subsection{FHLBanks’ primary borrowers}

Large U.S. financial institutions are the largest recipients of funding from the FHLBank System. Indeed, U.S. commercial banks with assets greater than $\$ 250$ billion accounted for approximately 31 percent of total FHLBank advances as of June 2017, up from about 20 percent a decade ago. ${ }^{28}$ Three of the five largest U.S. bank holding companies accounted for about 24 percent of the total par value of advances outstanding as of June 2017. JPMorgan Chase \& Co., Wells Fargo \& Co., and Citigroup Inc. reported advances of \$68 billion (or 10 percent of total par value), $\$ 63$ billion (9 percent) and $\$ 36$ billion (5 percent), respectively. ${ }^{29}$ The FHFA, the primary regulator of the FHLBanks, has noted that large member concentration remains an area of supervisory focus. ${ }^{30}$

Over the past few years, JPMorgan, Wells Fargo, and Citigroup have increased their aggregate FHLBank funding. The funding comes from multiple FHLBanks because the three have subsidiaries that are members of multiple FHLBanks (see Figure 7).

Figure 7: Trends in FHLBank borrowings by the three largest recipients of advances (annual).
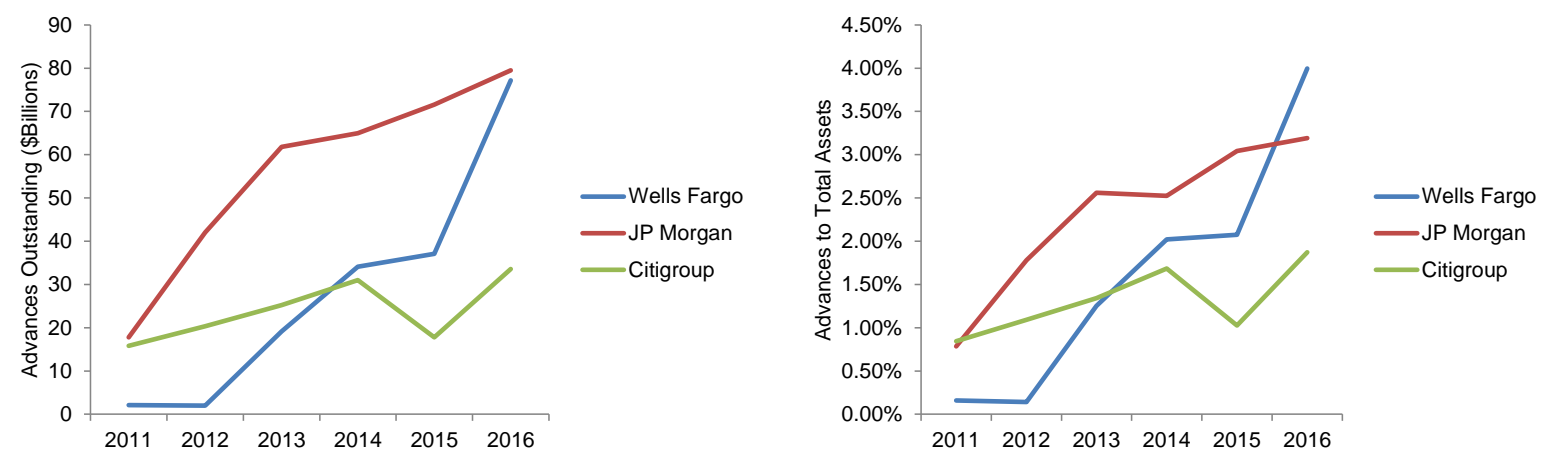

Source: FHLBanks' public SEC filings, firms' SEC 10-K and 10-Q filings. Data are annual and through December 2016.

\footnotetext{
${ }^{28}$ Authors' calculations based on Federal Financial Institutions Examination Council call reports and FHLBank Office of Finance data.

${ }^{29}$ In addition to JPMorgan, Wells Fargo, and Citigroup, rounding out the five largest borrowers are: Bank of America (\$23 billion or 3 percent) and PNC Financial (\$19 billion or 3 percent). http://www.fhlbof.com/ofweb userWeb/resources/2017Q2CFR.pdf

${ }^{30}$ See FHFA Director Melvin Watt's speech at the 2017 FHLBank director's conference, https://www.fhfa.gov/Media/PublicAffairs/Pages/Prepared-Remarks-of-Melvin-L-Watt-Director-of-FHFA-FHLBank-DirectorsConference.aspx. Watt expressed similar concerns in a May 2016 speech to the same group. See https://www.fhfa.gov/Media/PublicAffairs/Pages/Remarks-of-FHFA-Director-Watt-at-2016-FHLBank-Directors-Conference.aspx
} 


\subsection{FHLBanks' borrowings from money market mutual funds}

FHLBank debt held by money market funds has increased rapidly since 2014 (see Figure 8). Indeed, money market funds held about $\$ 546$ billion in debt issued by the FHLBanks or 19 percent of $\$ 2.9$ trillion in total money fund assets as of month-end July 2017. That total was up from $\$ 268$ billion in January 2014, or around 9 percent of the total money fund assets at that time. This swift increase in government money funds' holdings of FHLBank debt roughly coincides with U.S. banks' increased borrowing from the FHLBank System. It appears the growth was fueled by the intersection of two regulatory reforms - money market fund reforms, adopted in 2014 and fully-implemented in 2016, and U.S. LCR, finalized in 2014 and phased in from 2015 through $2017 .^{31}$

Figure 8: FHLBank debt held by money market funds.

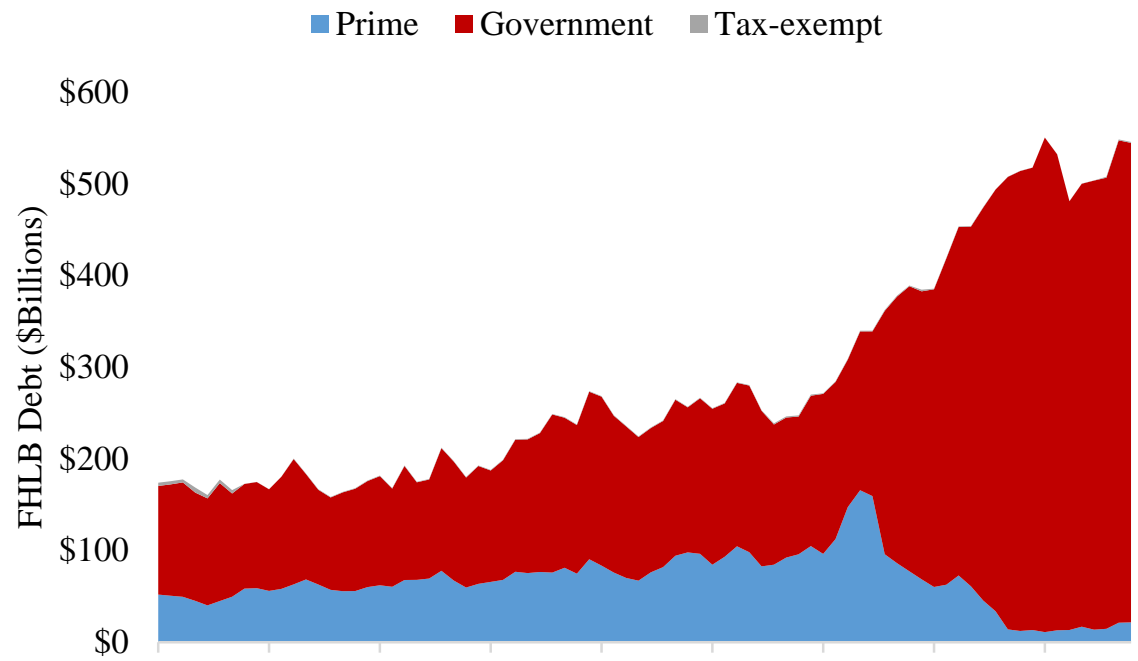

Jan-11 Oct-11 Jul-12 Apr-13 Jan-14 Oct-14 Jul-15 Apr-16 Jan-17

Source: SEC Form N-MFP. Data are monthly through August 2017.

Money market funds now hold over 50 percent of total (including discount notes and floaters) FHLBank debt outstanding as of August 2017, up from less than 35 percent in 2014 (see Figure 9).

\footnotetext{
${ }^{31}$ Our observations are based on available data. Establishing exact causation requires additional research and statistical testing. 
Figure 9: Fraction of total FHLBank System debt held by money market funds.

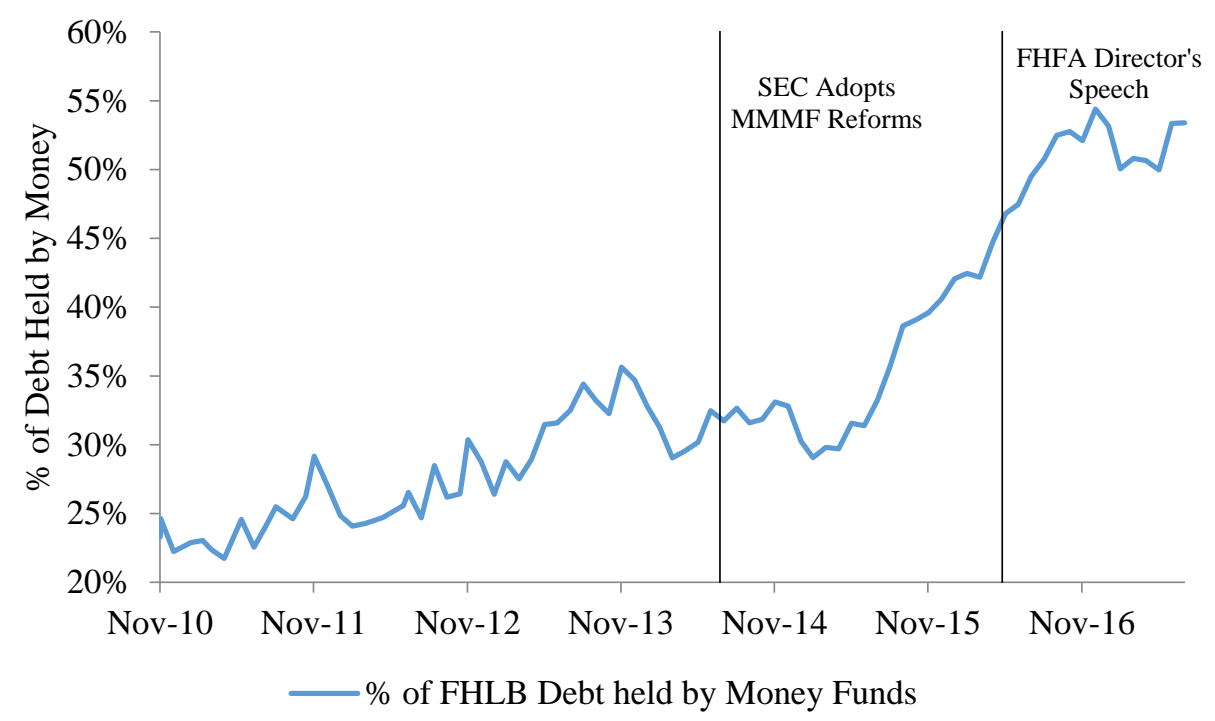

Sources: FHLBanks' public SEC filings, SEC Form N-MFP. Data are monthly through August 2017.

Note: The FHFA director first publicly expressed concerns with the FHLBank System's use of short-term funding.

The asset-liability profile of the FHLBank System has changed over the past years. The average maturity of debt issued by the FHLBanks has decreased since 2014, driven, in part we believe, by increased demand from government money market funds looking to purchase eligible short-term debt. Indeed, the FHLBanks have increased their issuance of discount notes, which generally mature within 90 days over the past few years. ${ }^{32}$ As money funds are subject to a weighted average maturity (WAM) limit of 60 days, FHLBank discount notes present an attractive, eligible investment option for government money funds because they offer yields that are higher than comparable U.S. Treasuries. We note that the increased demand from government money market funds has aligned closely with the increase in the percentage of total FHLBanks' liabilities represented by discount notes (see Figure 10).

In addition, beginning in 2016, FHLBanks have also increased their issuance of floatingrate notes. FHLBanks' floating-rate notes present an attractive investment opportunity for government funds - and other investors — that are expecting a rising interest rate environment. Furthermore, the periodic interest rate resets of such notes (generally monthly or quarterly)

\footnotetext{
${ }^{32}$ The weighted average maturity of discount notes from January 2008 through July 2017 is about 56 days. This is computed as the monthly issuance-weighted average of the weighted average maturity of discount notes.
} 
minimizes the impact such securities may have on a fund's WAM. However, the degree to which money funds may purchase floating-rate notes, particularly those that have relatively longer final maturities, may be constrained by the money fund rule's 120-day weighted average life requirement. $^{33}$

Against the backdrop of increasing shorter-term liabilities as a fraction of total liabilities, long-term advances (based on contractual maturity or next call date) have remained relatively stable as a percentage of total advances, which account for over 60 percent of total assets. Since FHLBanks are arguably using at least a portion of the proceeds of discount notes to finance longer-term advances to large financial institutions (see Figure 6), it appears that the FHLBank System's overall maturity transformation has increased over this period. ${ }^{34}$

Figure 10: Ratio of FHLBanks' discount notes to total liabilities, and longer-term advances to total advances.

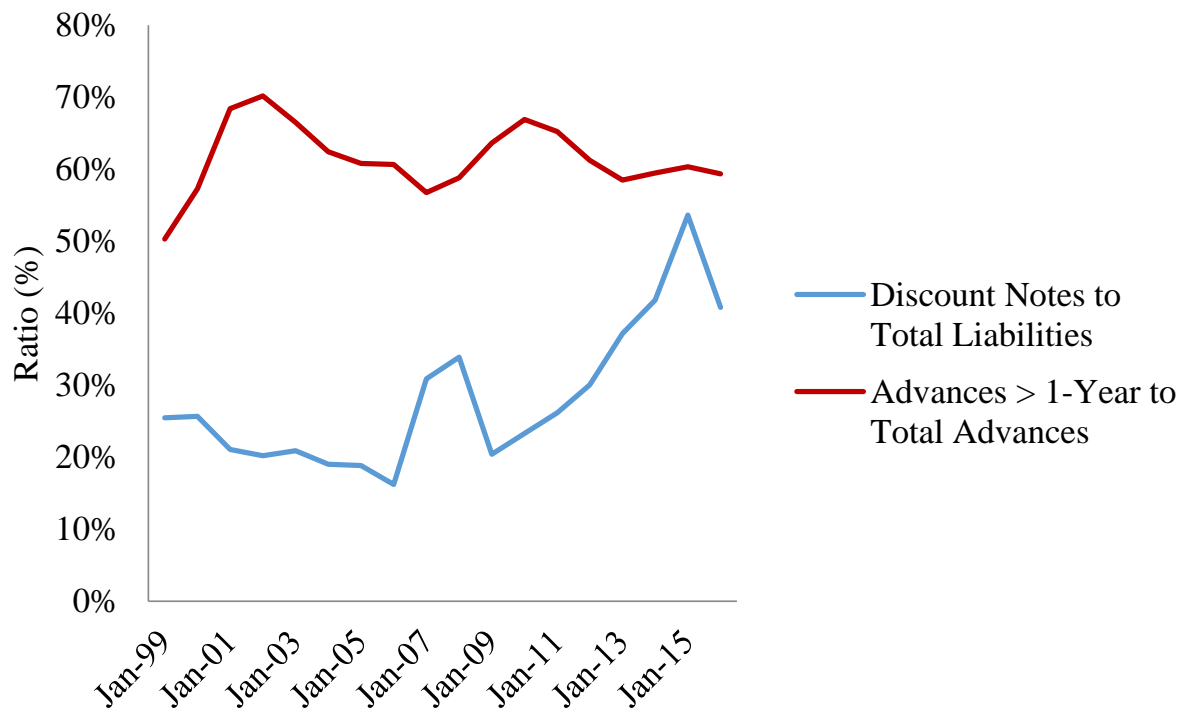

Source: FHLBanks' public SEC filing, Authors' calculations. Data are annual through December $2016 .{ }^{35}$

\footnotetext{
${ }^{33}$ WAM takes into account a security's maturity-shortening provisions (e.g., date of next interest rate reset) in computing its maturity contribution; whereas weighted average life, or WAL, uses the security's stated final maturity date.

${ }^{34}$ We note that the fraction of discount notes to total liabilities and long-term advances to total advances have both declined over the past few quarters. This may be related to the FHFA's publicly expressed concerns with the FHLBanks' reliance on shortterm debt to fund longer-term assets, discussed in Section 4.

${ }^{35}$ The ratio of advances greater than one year to total advances outstanding is derived using advances with contractual maturities greater than one year. We hypothesize that borrowers are less likely to prepay loans during periods of heightened market stress, particularly if their demand for liquidity is high. We exclude overdrawn demand and overnight deposits accounts, which are generally small, from our computation.
} 


\subsection{Money market mutual funds' investments in other U.S. government and GSE securities}

In addition to increased investments in short-term debt issued by the FHLBank System, money market funds have also increased their investments in U.S. Treasury securities, which reached an all-time high of $\$ 921$ billion at month-end October 2016 and have since declined (see Figure 11). The issuance of short-term U.S. Treasury securities is not sizable enough to satisfy the increased demand from government funds (and other exogenous demand for short-duration, high quality assets) given the U.S. Treasury's objective to increase the weighted-average maturity of its marketable debt portfolio. ${ }^{36}$

Money funds' investments in debt issued by Federal Home Loan Mortgage Corporation (FHLMC) and Federal National Mortgage Association (FNMA) have also declined. This is because both agencies are reducing the size of their balance sheets, and thus borrowing less in the money markets. The FHLBanks, whose prominence as an intermediary between money market funds and its members have increased over the years, has been in a position to capitalize on this demand imbalance.

These data illustrate the substantial demand for short-term government securities from money market funds amid somewhat limited channels to meet such demand. ${ }^{37}$ We discuss potential implications of this in the next section.

Figure 11: Money market funds' investments in select government and agency securities.
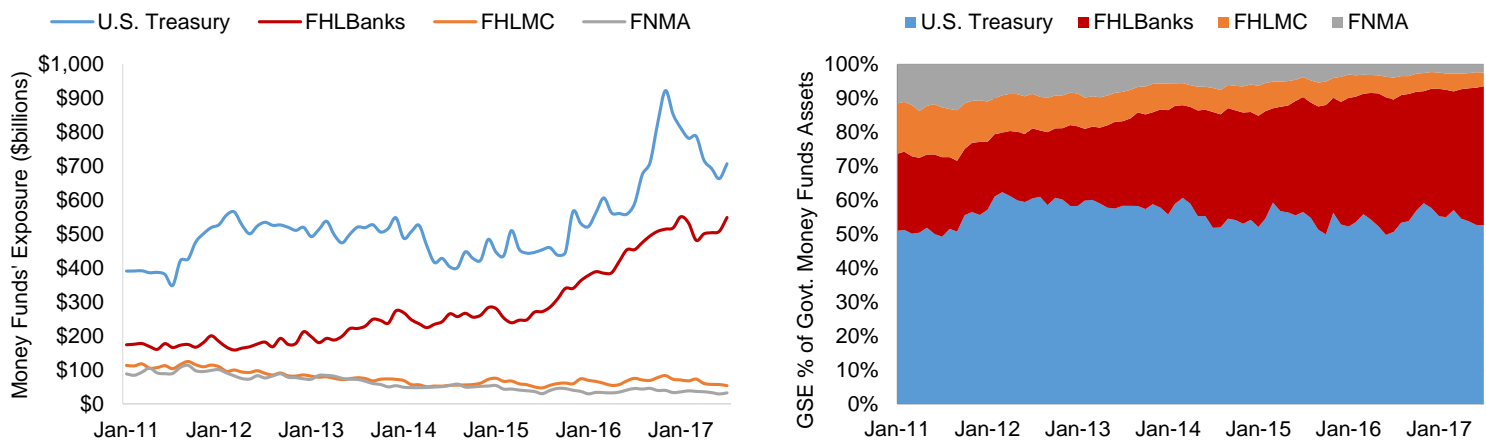

Source: SEC Form N-MFP. Data are monthly through August 2017.

\footnotetext{
${ }^{36}$ See https://www.treasury.gov/press-center/press-releases/Pages/jl0672.aspx.

${ }^{37}$ To be sure, other post-crisis regulations have likely contributed to the increased demand for government securities (and other high-quality liquid assets), including the liquidity coverage ratio and central counterparty clearinghouses for clearing certain swaps.
} 


\section{FHLBanks' Short-term Borrowings and Potential Vulnerabilities}

Money market fund reform has arguably increased the demand for FHLBank debt by government funds. This, in turn, supports the FHLBank System's ability to provide funding (via advances) to large financial institutions, effectively serving as a financial intermediary between funds and large U.S. financial institutions. The highly stylized transactions below provide some intuition on how a specific transaction may have evolved in response to money fund reforms.

Figure 12: Stylized example of intermediation between money market funds and the FHLBanks

Transaction 1

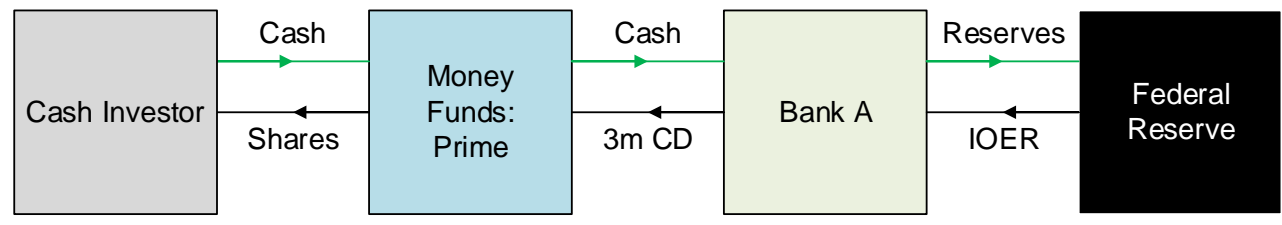

Transaction 2

\begin{tabular}{|c|c|c|c|c|c|c|c|c|}
\hline \multirow{3}{*}{ Cash Investor } & Cash & & Cash & \multirow{3}{*}{$\begin{array}{c}\text { FHLBank } \\
\text { System }\end{array}$} & Cash & \multirow{3}{*}{ Bank A } & Reserves & \multirow{3}{*}{$\begin{array}{l}\text { Federal } \\
\text { Reserve }\end{array}$} \\
\hline & & $\begin{array}{l}\text { Money } \\
\text { Funds. }\end{array}$ & & & & & & \\
\hline & Shares & Government & $\begin{array}{l}6 \mathrm{~m} \\
\text { Note }\end{array}$ & & $\begin{array}{c}6 \mathrm{~m} \\
\text { Advance }\end{array}$ & & IOER & \\
\hline
\end{tabular}

Source: Authors' analysis.

In Transaction 1 (pre-reform), Bank A borrows term CD from a prime money fund, and then "parks" that cash at the Federal Reserve. All else equal, this transaction is accretive to Bank A's LCR, as it increases its stock of HQLA. In Transaction 2, the FHLBank System borrows from government money market funds (e.g., 180 day notes) and then makes advances to Bank A. Similar to the first transaction, Bank A uses this cash to fund its stock of HQLA. Under both transactions, Bank A is able to fund its portfolio of HQLA by borrowing from money market 
funds; in the second, however, there is an additional intermediation chain through FHLBank System. $^{38}$

One concern is the FHLBanks' increased reliance on short-term funding could be vulnerable to rollover risks if cash investors' risk appetite for GSE debt were to unexpectedly change. As GSEs, FHLBanks are perceived as enjoying an implicit guarantee from the U.S. government. However, any uncertainty about this GSE status, for example due to changes in the regulatory or legislative environment, could challenge the FHLBanks' ability to rollover their debt. Moreover, an implicit guarantee does not necessarily mean that the U.S. government will step in if the FHLBank System were to experience material distress. The FHFA, the primary regulatory of the FHLBank System, has expressed concerns with the FHLBank System's increased issuance of short-term funding, citing potential safety and soundness issues that may emanate from rollover risk, including in periods when interest rates are rising. ${ }^{39}$

Another consideration is the possible return of assets into prime funds, which could reduce demand for the FHLBank System's debt. However, a rapid, large-scale migration of assets from government funds into prime funds seems unlikely absent a reversal of the SEC's 2014 amendments. Furthermore, prime money market funds might want to hold FHLBanks' discount notes with 60 days or less to maturity because these notes qualify as "weekly liquid assets."40 Nevertheless, unexpected changes to the FHLBanks' funding sources may, as previously noted, expose them to rollover risks.

By borrowing from government money market funds on a significant scale and lending substantially to a handful of the largest banks, FHLBanks' funding model may be vulnerable to a funding shock that could spill over into the broader financial system. The potential implications of a funding shock would depend on the speed of the pullback from money market funds and its

\footnotetext{
${ }^{38}$ In our examples, the bank borrowings mature outside of the 30 day window meaning there is no corresponding outflow under LCR. For more on this borrowing dynamic, see: Zoltan Pozsar's "Global Money Notes \#9: Excess Reserves and Global Dollar Funding," 2017, https://research-doc.creditsuisse.com/docView?language=ENG\&format=PDF\&sourceid=em\&document id=1073509641\&serialid=ECkho4yNa8FtYN7rZhaV O\%2BIA4dDplrVyfzgZA4M2xeY\%3D

${ }^{39}$ See FHFA Director Melvin Watt's speech at the 2017 FHLBank directors conference, https://www.fhfa.gov/Media/PublicAffairs/Pages/Prepared-Remarks-of-Melvin-L-Watt-Director-of-FHFA-FHLBank-DirectorsConference.aspx. His speech at the 2016 event is at https://www.fhfa.gov/Media/PublicAffairs/Pages/Remarks-of-FHFADirector-Watt-at-2016-FHLBank-Directors-Conference.aspx. For information on FHLBank discount notes, see http://www. fhlbof.com/ofweb userWeb/pageBuilder/about-discount-notes-41

${ }^{40}$ The SEC requires taxable money market funds to invest at least 30 percent of their assets in weekly liquid assets, see https://www.sec.gov/rules/final/2014/33-9616-rule-2a-7-amendments.pdf
} 
magnitude. One hypothetical scenario is that FHLBanks would be unable to rollover their liabilities and would be unable to rollover maturing advances to FHLBank members, including large banks. Unexpected funding shocks to FHLBank System could have negative implications for the availability of funding to the FHLBanks' members. This includes the largest U.S. banks, particularly those that may be funding HQLA with FHLBank advances. More broadly, the FHLBank System directly and indirectly plays a role in other markets, including the federal funds market, interest rate derivatives market, and mortgage markets, which may be impacted by stresses at the FHLBank System in ways that are difficult to envision.

While we have described some potential risks and transmission channels, it is important to acknowledge that the probability of material distress to the FHLBank System appears low, particularly on the asset side given the system's recourse to collateral underlying advances. Nonetheless, we highlight these potential implications because it is generally the violation of widely held assumptions that have tended in the past to pose or contribute to financial stability issues.

\section{Conclusion}

The liquidity coverage ratio generated demand from large U.S. banks for substantial amounts of new advances to meet their regulatory requirements. Separately, money market fund reforms have prompted a significant shift in assets from prime money market funds into government funds. FHLBanks have met this increased demand for advances to members and short-term government securities with increased issuance of short-term and floating-rate debt eligible for investments by money market funds. Analysis of regulatory filings by FHLBanks finds that this increased funding is largely used to subsidize regulatory liquidity requirements to the largest U.S. banks. ${ }^{41}$ The FHLBanks are increasingly serving as a link between money market funds, primarily government funds, and the largest U.S. banks, and this link may generate new unintended vulnerabilities to the U.S. financial system.

Although a low probability event, potential risks channels include a run on FHLBanks' liabilities due to uncertainties about their GSE status, operational issues that limit the FHLBanks' ability to rollover its debt, or other events that cause a rapid shift in investors' preferences. The

\footnotetext{
${ }^{41}$ See W. Scott Frame (2016).
} 
prospect of such an event warrants close monitoring, as it could impact the broader financial markets in ways that are difficult to predict. The FHFA is aware of the increased maturity mismatch and is taking steps to reduce the system's reliance on short-term funding, including its plan to issue proposed liquidity risk management rules by year-end. ${ }^{42}$

\footnotetext{
42 In his May 2017 remarks at the 2017 Federal Home Loan Bank Director's Conference, FHFA Director Watts noted "...we [FHFA] intend to issue a proposed liquidity rule by the end of this year," https://www.fhfa.gov/Media/PublicAffairs/Pages/Prepared-Remarks-of-Melvin-L-Watt-Director-of-FHFA-FHLBank-DirectorsConference.aspx
} 